\title{
Generational Perspectives of the Export Behavior
}

\section{of Family Businesses}

\author{
Sam C. Okoroafo (corresponding author) \\ College of Business Administration, The University of Toledo \\ 2801 W. Bancroft Street, Toledo, Ohio 43606-3390 USA \\ Tel: 419-530-4398Ｅ-mail: Sam.Okoroafo@UToledo.edu \\ Morys Perryy \\ School of Management, University of Michigan-Flint
}

3180 William S. White Building, 303 E. Kearsley, Flint MI 48502-1950 USA

Tel: 810-237-6589Ｅ-mail: morys@umflint.edu

The authors wish to acknowledge financial support from the Center for Family Business in the College of Business Administration at the University of Toledo, Ohio USA.

\begin{abstract}
The purpose of this exploratory study is to compare the views and export behavior of family businesses run by 'first', 'second' and 'third'generation owners. It is common to ascertain different generational perspectives and its impact on strategy and performance. It is hoped that conclusions can be derived as to the impact of succeeding generational owners on export activities.Specifically, whether exporting views and behavior exacebate with nwer generations. A mail survey of US family business owners based in Ohio was conducted. Comparative responses in awareness and usage provided by the first, second, and third generation owners were obtained. The results revealed second generation owners were more receptive to export involvement (unsolicited, solicited orders, etc.). They also used more government services designed to help exporters (e.g., promotion, getting export leads, etc.). However, both the first and second generationers were split on their use of export payment tools (drafts, letters of credit, etc.) and domestic intermediaries (export trading and management companies, etc.).
\end{abstract}

Keywords: Export Behavior, Internationalization, Family Businesses, Views, Generations

\section{Introduction}

US exporters continue to be challenged in foreign markets. Since 1973, the US has run a persistent trade deficit, sometimes as high as US\$700 billion a year. Part of the cause is that export participation and exporting levels of US firms are still low. As the US Commerce department has reported, only 240,000 small and medium sized companies (the bulk of which are family businesses) export a third of US merchandise exports (Reilly and Murphy 2009). Given that family businesses constitute $90 \%$ of US businesses and account for $60 \%$ of employment (Family Business Statistics 2009), their export activities is critical to ameliorating the trade deficit and elevating employment and growth levels (Chen 2009). So it is seems clear that US family businesses that are typically small and medium sized enterprises (SME) are not actively exporting in proportion to their numbers. For family businesses, their internationalization and exporting strategies are largely unknown (see, Carrigan and Buckley 2008; Cooper et. al. 2005). While some studies have looked at the export behavior of firms from India (Lal 2004), UK (Gourlay and Seaton 2004), Italy (Castellani 2002), Spain (Vila Lopez 2007), developing economies (Tyagi 2000), Australia (Julian and Ahmed 2005), etc., few have focused on family businesses. Exceptions include Fernandez and Nieto (2005) and Claver, et. al. (2009) that addressed some aspects of export behavior of family businesses! Even fewer studies have investigated the impact of generational differences within family businesses on export behavior.

This exploratory study is to compare the exporting views and behavior of family businesses (henceforth, FOBs) run by 'first', 'second' and 'third' generation owners. By comparing differences in exporting views and behavior, it is hoped that conclusions can be derived as to the impact of succeeding generational owners on export behavior. After all, a relationship exists between export intention and activity (Morgan and Katsikeas 1997). It could also provide clues as to the export involvement levels of FOBs in foreign markets. This finding can be useful in getting more US family businesses involved in exporting.

This study contributes by investigating differences in multi-generation owner perceptions of exporting behavior. 
Specifically, what were their export stimulants? What US department of commerce services is used? What types of export payment arrangements are used? What types of export intermediaries are used? And what types of export financing tools are used? These issues have not been addressed in the literature.

Organizationally, the paper next provides a brief overview of the theoretical and conceptual foundations. In the third section, the research methodology is explained. Then the results are presented. Finally, the conclusions, recommendations, and future research directions are provided.

\section{Conceptual Origins}

\subsection{Why does Generational Ownership make a difference?}

The presence of generations is the endearing difference between family businesses and non-family businesses (Debicki, et. al. 2009). Attitudes and behaviors of family businesses can vary by generation (Welsch, 1991; Swinth and Vinton, 1993). There is some information about the attributes and motivations of founders $\left(1^{\text {st }}\right.$ generation) and successors (Chrisman et. al. 1998; Sharma and Rao 2000; Handler 1994). For instance, Sharma (2004) summarizes writings from various studies and concluded that founders exert considerable influence on the culture, values, and performance of the company (p10).

An area where generational ownership has been studied is entrepreneurship. However, studies have found a strong correlation in behavior by different generations. For instance, age of the CEO did not predict greater tendencies to be entrepreneurial (de Pontet et. al. 2007) or internationalization (Davis and Harveston 2000). Lee (2006) did not find a significant relationship between CEO age and entrepreneurship. This findings was further confirmed by Kellermanns et. al. (2008) that stated that "even if a family firm member becomes a CEO at a young age, he or she may not have the power to enact entrepreneurial behavior (p.8)." But, Lee (2006) cautions "family business owners to exercise a certain degree of flexibility (p.187)" to entice younger generations to stay. This implies that cases of extreme differences may result in organizational conflict, possibly leading to exit. In conclusion, it appears the selection and grooming process in family businesses is designed to identify smiliarities rather than differences (Cater and Justis 2009). The expectations for exporting behavior is different.

\subsection{Export Behavior of Small and Medium Firms}

Regarding the services provided by the federal government targeted at US exporters, Vanderleest (1996) surveyed small businesses (most of which likely would be FOBs) in Indiana to determine their awareness and perceived usefulness. He found varying degrees of awareness and perceived usefulness. Awareness of services ranged from $25.2 \%$ for comparison shopping service to $94.3 \%$ for export seminars. However his sample was not specific to family businesses. Moini (1998) survey of small and medium sized Wisconsin firms found that their awareness and effectiveness of export assistance programs varied by degree of internationalization. Some studies not focusing specifically on family businesses have insights of export behavior (e.g., Julian and Ahmed 2005). For instance, firms at different stages of exporting or international involvement and expansion will exhibit different behaviors regarding information gathering, motivation for initial exports, market focus, export channels used, etc. (Leonidou 2004 for a review). Also, firms at different stages of internationalization exhibited different characteristics regarding sales, export sales level, etc (Ortiz-Buonofina 1991; Moen and Servais 2002). Denis and Depelteau (1985) looked at how exporters meet their information needs and found that the reliance on trade "fairs" and "missions" depended on whether the firm was a new or experienced exporter.

\subsection{Export Behavior of Family Businesses}

Fernando and Nieto (2005), in their study on internationalization used two export related measures to determine the extent of internationalization of family businesses. Their study addresses the "export stimulant" question in our research. They found that family businesses export less in proportion to other small and medium firms. Another research, Okoroafo (1999) found that majority FOBs were active or committed exporters. Also, they were motivated initially by "unsolicited orders" but their awareness and use of Federal government services was limited. Further, typical export instruments used was the 'letter of credit.' Unfortunately, this study did not compare activities by generation. This study fulfills this gap.

\subsection{Export Behavior by Generations}

This study focused on six aspects of export behavior- export stimulants, US department of commerce services used export payment arrangements used, export intermediaries used and export financing services used. Not much has been written pertaining to family businesses on these issues. On exception is Westhead et. al. (2001). They tried to identify factors that encourage owner managed small businesses to enter export markets. They found that older principal owners $\left(1^{\text {st }}\right.$ generation) with more resources, denser information and contact networks, and considerable management knowhow were significantly more likely to be exporters. Also, Fernandez and 
Nieto (2005) found that in exporting FOBs, second and subsequent generation ones show higher export propensity and intensity than do first generation ones. Also, Claver, et. al. (2009) did not find support for the notion that later generations use higher level entry modes (e.g., investments). This suggests that subsequent generation owners of family businesses will opt for lower level entry modes (e.g., exporting).

\section{Research Design}

A mail survey of family businesses from Northwest Ohio, USA was done. The objective of this study was to compare the export views and behavior of family businesses run by first, second, and third generation owners.

\subsection{Questionnaire}

The questionnaires were designed to first screen out non- family business owners and determine their current generation status. Eight five (85) percent of the respondents identified themselves as family businesses. The following six questions were asked of all family business respondents.

wFor exporting family businesses, the following questions were asked.

- What were their export stimulants? [Alternatives provided]

- What US department of commerce services is used? [Alternatives provided]

- What types of export payment arrangements are used? [Alternatives provided]

- What types of export intermediaries are used? \{Alternatives provided]

- What types of export financing and insurance services are used? [Alternatives provided]

\subsection{Scale and Analysis}

The percentage of family businesses being run by the first, second, and third generations were $38.1 \%, 37.5 \%$, and $18.8 \%$ respectively. First generation owners are typically the founders, who then turn over control to their children or nieces/nephews (second generation). The off springs of the second generation owners would constitute the third generation. Categorical scales (unaware/ aware/ used and yes/no) and were used for all questions. Nominal scales are typically used for internationalization research where responses by percentages are desired. So, Pearson's chi squared goodness of fit analysis was used to test for significance on responses to the six questions.

\subsection{Sample}

The sample frames used were Ohio Manufacturers Directory and the University of Toledo Center for Family Business membership roster. Five hundred firms were selected from counties identified by the former source as constituting "Northwest Ohio". Respondents were dispersed across all industrial sectors with the most being manufacturers of machinery and computers $(21 \%)$, food and kindred products $(9 \%)$, fabricated metal products $(9 \%)$, rubber and plastic products $(5 \%)$, and primary metals $(5 \%)$. Their self reported annual sales ranged from $\$ 500,000$ - $\$ 10$ million with most having sales of $\$ 1-\$ 5$ million annually. The top two categories in terms of annual sales were $\$ 1-\$ 5$ million (36\%) and above \$10 million (19\%).

\subsection{Mailing Frequency and Response Rates}

A pre-test and two mailings were done. A pretest using 50 randomly selected respondents generated 14 responses ( $28 \%$ response rate). The initial mass mailing of 450 generated 125 responses ( $27.77 \%$ response rate). A follow up mailing to 361 non-respondents from the pretest and initial mailing generated 57 additional responses ( $15.8 \%$ response rate). Thus, a total of 196 responses were received of which 187 were usable. The effective response rate for the study was 37.4 percent.

\section{Data Interpretation and Results}

In interpreting our findings in Tables $1-4$, we noted that proportion of $1^{\text {st }}$ generation and $2^{\text {nd }}$ generation were roughly equivalent ate $38.1 \%$ and $37.5 \%$ respectively. So, care needs to be taken in comparing the numeric differences with respect to the $3^{\text {rd }}$ generation that proportionally constituted only $18.8 \%$. Also, it should be pointed out that early generationers are the $1^{\text {st }}$ and $2^{\text {nd }}$ owners, while later generation refers to the $3^{\text {rd }}$ generation owners. Also, some of the significance interpretation was based on the 'likelihodd ratios' as opposed to 'chi-squared'. Likelihood ratios is an alternative procedure to determine significance for samples. It can be interpreted in much the same way as Pearson's chi square, even for smaller samples (Garson 2009)

\subsection{Export Stimulants}

As discussed earlier, the factors that stimulate firms to initially export have been of interest to scholars. So, our findings (see, Table 1) as to whether these factors differed based on whether exports was initiated during the first, 
second, or third generations revealed some interesting insights.

Firms have reported being motivated by 'unsolicited orders' (Bilkey 1978). Our research show that $2^{\text {nd }}$ generationers were most influenced by unsolicited orders. Also, solicited orders was the the motivation for $2^{\text {nd }}$ generation firms. Foreign travel was the equal motivator for $1^{\text {st }}$ and $2^{\text {nd }}$ generation firms, while 'news sources' was the primary motivator for $1^{\text {st }}$ generationers. 'Friends' had the most influence on $2^{\text {nd }}$ generation exporters, while 'business associates' had the most impact on $1^{\text {st }}$ generationers. Finally, early generation exporters were just about equally influenced by the desire to 'expand their markets overseas.'

\subsection{Use of US Department of Commerce Services}

The results (see, Table 2) were all significant at the .05 level. The services provided to exporters are designed to help them become export competitive. One of these services is providing information about foreign markets. Everything from country reports to websites is available for a small fee. Unfortunately,

This service is not generally family to $1^{\text {st }}$ and $2^{\text {nd }}$ generation owners. Although, $3^{\text {rd }}$ generation were less aware, but were not more aware or have used it. The early generations were 'more aware' and have 'used' their research sources. More specialized information about product competitiveness is also provided. Our respondents indicate more $2^{\text {nd }}$ generationers are aware of theses services, while more $1^{\text {st }}$ generationers had used it.

Another service provided is promotion of products overseas. Tools such as magazine, videos, and one-on-one promotion are available for a minuscle fee. The picture that emerges is that $1^{\text {st }}$ and $2^{\text {nd }}$ generation owners are more 'unaware', 'aware', and have 'used' them. And the usage rates are low.

Identifying foreign partners is an important aspect of export success. So the department provides services to aid exporters find of foreign repressentatiives. Unfortunately, these service is not well known. The $2^{\text {nd }}$ gebneration is more knowledgeable and have used it more than the other two. A related issue is verifying the credibility of foreign partners. Similar results were here-early generation $\left(1^{\text {st }}\right.$ and $\left.2^{\text {nd }}\right)$ owners are most likely to be 'unaware,' 'aware' and have 'used' them.

Obtaining export leads to customers providing similar results in terms of early generation owners being more aware. More $1^{\text {st }}$ generation owners are 'unaware' of this service, while more $2^{\text {nd }}$ generation owners were aware of it. Also, $2^{\text {nd }}$ generationers have used it.

Having the necessary exporting skills is critical to success. So, some services are directed to help ungrade this exporting skills. Again, $3^{\text {rd }}$ generation owners are least likely to be aware of or have availed themselves of the counseling services. More $1^{\text {st }}$ generationers were unaware of it, or more $2^{\text {nd }}$ generationers were aware of it. Both early generation owners had used counseling in equal proportions.

\subsection{Export Payments}

Table 3 shows the results based on the questions posed. Overall, there were significant generational differences in the level of awareness and usage of export payment instruments. Second generation owners were most aware of consignment sales, while first generation owners would have used it more than subsequent generations. Also, third generation owners were least aware of consignment sales relative to the first and second generation. The picture emerging here is that subsequent generations of owners are least likey to be aware of or have used consignment sales. Given that consignment sales is the most risky instrument for the exporter, it is surprising that early generation owners used it.

The results pertaining to 'open accounts' was also significant. In this case, the first and third generation owners were more likely to be 'aware' of open accounttransaction, while the second generation have 'used' it. For drafts, the second geberation were more likely to be 'aware and used' it. Letters of credit instrument was most likely used by $2^{\text {nd }}$ generation owners. In all, $3^{\text {rd }}$ generated were least likely to be aware or used' this method.

\subsection{Use of Domestic Intermediaries.}

Domestic intermediaries are institutinal arrangements (e.g., export management companies, piggyback exporters, etc.) that help US exporters execute the delivery of products to overseas buyers. Intermediaries perform fucctions such as transportation, storage, and transaction consummation. The extent to which these intermediaries are known and used was the purpose of questioning here.

Table 4 presents the outcomes (all significant). When a more experienced firn (carrier) provides exporting services to a smaller exporter (rider), it is referrwed to as piggybacking. The results of the survey show that first generation owners were less aware o fthem. While more second generationers were aware of them, fewer had used them. Second generationers were more aware of export trading comapnies and uses them at the same rate of second generationers. Export maangement companies were equally known and used by both first and second 
generationers. Foreign sales represenatives were more known to first generationers, but the second generationers had used it more.

\section{Conclusions}

What emerges is a picture where the $2^{\text {nd }}$ generation exporters are more receptive to many of the typical stimulants of exporting (solicited and unsolicted orders, foreign travel, etc.). On the other hand, first generationers were more influenced by business associates. This suggests that second generationers are more open to new ideas and revenue enhancement opportunities. The scenario could be that a second generation firm, having survived the firms 'start-up' challenges, has witnessed some stagnation in sales which makes them more receptive to growth opportunities. This conclusion however may not be universally accurate as a new type of firms - born globals are emerging. Born-globals are firms that internationalize from the outset (see, Chetty and Campbell-Hunt, 2004).

On the use of services offered to exporters through the US department of commerce, again it appears that second generationer were more aggressive in using them. The second generationers had used services that promote their products overseas, identify and check the credibility of foreign partners, obtain export leads. However, the first generationers had made more use of customized reports on foreign markets.

Do preferred export payment arrangements vary by generations? The results here were mixed. First generationers prefer to use consignments sales, while second generationers have used open accounts, drafts, and letters of credit. Awareness of these instruments were reported more for consignment sales, drafts, and forfaiting by second generationers. Alternatively, first generationers are more aware of open accounts and letters of credit.

Exporting can be facilitated by domestic intermediaries. The results were mixed. First generationers were more aware of the existence of export trading companies and foreign trade representatives. Also, the first generationers have used piggybacking and export management companies. Second generationers have used foreign sales representatives more than the first generationers.

In summary, unlike previous studies that have shown that succession to the second generation does not always lead to internationalization (Fernando and Nieto 2005; also, see Graves and Thomas 2008), our findings suggest some differences in motivation and propensity to use government services.

\section{Recommendation}

Based on our findings, it appears that second generationers are more susceptible to export participation. Therefore we would suggest that family businesses target this group with information and training to improve export performance.

\section{Further Research Issues}

Getting views on internationalization of FOBs from other nations will provide a more robust assessment of this issue. If generational differences in views are obtained, emphasis should be focus on the younger generation. However, it would be interesting to determine the proportion of family businesses that are 'born-global.'

\section{Limitations.}

It should be noted that firms can be at different stages of exporting (Cavusgil 1984; Aspelund and Moen 2001). Our study did not account for these stages in our analysis. Given the typical sales level of our sample (US\$1-5 million), we assumed that they will be "experimental' rather than "committed." exporters. That is because Cavusgil (1984) found those firms with less than 10 million US dollars in annual sales tended to be "experimental", not "active" or "committed" exporters.

\section{References}

Aspelund, A. \& Moen O. (2001). A Generation Perspective on Small Firm Internationalization: From Traditional Exporters and Flexible Specilists to Born Globals. Advances in International Marketing, 11, 197-226.

Carrigan, M. \& Buckley, J. (2008). What's so special about family business? An exploratory study of Irish consumer experiences of family business. International Journal of Consumer Studies, 32(6), 656-666.

Cater, J. \& Justis, R. (2009). The Development of Successors from Followers to Leaders in Small Family Firms. Family Business Review, 22(2), 109-124.

Castellani, D. (2002). Export Behavior and Productivity Growth: Evidence from Italian Manufacturing Firms. Review of World Business, 138(4), 605-629.

Cavusgil, T. (1984). Differences among Exporting Firms based on their Degree of Internationalization. Journal 
of Business Research, 12, 195-208.

Chen, H. (2009). A Literature Review of the Relationship between Foreign Trade and Economic Growth. International Journal of Economics and Finance, 1(1), 127-130.

Chetty, S. \& Campbell-Hunt (2004). A Strategic Approach to Internationalization: A Traditional versus a Born-Global Approach, Journal of International Marketing, 12(1), 57-81.

Chrisman, J., Chua, J. \& Sharma, P. (1998). Important Attributes of Successors in Family Businesses: An Exploratory Study. Family Business Review, 11(1), 35-47.

Claver, E., Rienda, L. \& Quer, D. (2009). Family Firms' International Commitment: The Influence of Family-Related Factors. Family Business Review, 22(2), 125-135.

Cooper, M., Upton, N. \& Seaman, S. (2005). Customer Relationship management: A Comparative Analysis of Family and Non-family Business Practices. Journal of Small Business Management, 43(3), 242-256.

Davis, P. \& Harveston, P. (2000). Internationalization and Organizational Growth: The Impact of Internet Usage and Technology Involvement Among Entrepreneur-led family Businesses. Family Business Review, 13, 107-120.

Debicki, B. Matherne, C., Kellermanns, F. \& Chrisman, J. (2009). Family Business Research in the New Millenium. Family Business Review, 22(2), 151-166.

Denis, J. \& Depelteau, D. (1985). Market Knowledge, Diversification and Export Expansion. Journal of International Business Studies, Fall: 77-89.

de Pontet, S., Wrosch, C., \& Gagne, M. (2007). An exploration of the Generational Differences in Levels of Control held among Family Businesses Approaching Succession. Family Business Review, 20(4), 337-354.

Family Business Statistics. (2009). American Management Services, http://www.amserv.com/familystatistics.html

Fernandez, Z. \& Nieto, M. (2005). Internationalization of Small and Medium-Sized Businesses: Some Influential Factors. Family Business Review, 18(1), 77-89.

Graves, C. \& Thomas, J. (2008). Determinants of Internationalization Pathways of Family Firms: An examination of Family Influence. Family Business Review, 21(2), 151-167.

Garson, G. D. (2009). Chi-Squared Significance Tests. http://faculty.chass.ncsu.edu/garson/PA765/chisq.htm

Gourlay, A. \& Seaton, J. (2004). UK Export Behaviour at the Firm Level. Economic Issues, 9(2), 3-20.

Handler, W. C. (1994). Succession in family Business: A Review of the Research. Family Business Research, 7 (2), 133-157.

Julian, C. \& Ahmed, Z. (2005). The Impact of Barriers to Export on Export Marketing Performance. Journal of Global Marketing, 19(1), 71-94.

Kellermanns, F., Eddleston, K., Barnett, T. \& Pearson, A. (2008). An Exploratory Study of family Member Characteristics and Involvement: Effects on Entrepreneurial Behavior in the Family Firm. Family Business Review, 21(1), 1-14.

Lal, K. (2004). E-business and Export Behavior: Evidence from Indian Firms. World Development, 32, 505-518.

Lee, J. (2006). Impact of Family Relationships on Attitudes of the Second Generation in Family Business. Family Business Review, 19(3), 175-191.

Leonidou, L. (2004). An Analysis of the Barriers Hindering Small Business Export Development. Journal of Small Business Management, 42(3), 279-302.

Moen, O. \& Servais, P. (2002). Born Global or Gradual Global? Examining the Export Behavior of Small and Medium Sized Enterprises. Journal of International Marketing, 10(3), 49-72.

Morgan, R. \& Katsikeas, C. (1997). Export Stimuli: Export Intention Compared with Export Activity. International Business Review, 6(5), 477-499.

Moini, A. (1998). Small Firms Exporting: How Effective are Government Export Assistance Programs. Journal of Small Business Management, 36(1), 1-5.

Okoroafo, S. (1999). Internationalization of family Businesses: Evidence from Northwest Ohio, U.S.A. Family Business Review, 12(2), 147-158.

Ortiz-Buonafina, M. (1991). Export Marketing Activities in the Internationalization Stages of the Export Firm. Akron Business and Economic Review, 22(1), 45-55. 
Reilly, L. \& Murphy, J. (2009). Helping Small Businesses Export: Promotion Programs can bring Significant Gains. US Chamber of Commerce-International Policy backgrounder, March, .1-4.

Sharma, P. (2004). An Overview of the Field of family Business Studies: Current Status \& Directions for the Future. Family Business Review, 17, 1- 36.

\& Rao, A. (2000). Successor Attributes in Indian \& Canadian Family Firms: A Comparative Study. Family Business Review, 13(4), 313-330.

Swinth, R. \& Vinton, K. (1993). Do Family-Owned Businesses have a Strategic Advantage in International Joint Ventures? Family Business Review, 4, 19-30.

Tyagi, P. (2000). Export behavior of Small Business Firms in Developing Economies: Evidence from the Indian Marketing. Marketing Management Journal, 10, 12-20.

Vanderleest, H. (1996). What New exporters Think of US Government Sponsored Export Promotion Services and Publications. Multinational Business Review, Fall, 21-29.

Venter, E., Boshoff, C., \& Maas, G. (2005). The Influence of Successor-Related Factors on Succession Process in Small and Medium-Sized Family Businesses. Family Business Review, 18(4), 283-303.

Vila Lopez, N. (2007). Export Barriers and Strategic Grouping. Journal of Global Marketing, 20(2/3): 17-29.

Welsch, J. (1991). Family Enterprises in the United Kingdom, the Federal Republic of Germany, and Spain: A Transnational Comparison. Family Business Review, 4 (2), 191-203.

Westhead, P., Wright, M. \& Ucbasaran, D. (2001). Internationalization of New and Small Firms: A Resource-Based View. Journal of Business Venturing, 16, 333-358.

Table 1. Export Stimulants

Q1.1: Export Stimulant-Unsolicited Orders

\begin{tabular}{|l|l|l|l|l|l|l|l|}
\hline Response & $1^{\text {st }}$ Gen. & $2^{\text {nd }}$ Gen. & $3^{\text {rd }}$ Gen. & $\chi 2 \&$ Likelihood Ratios & df & Sig & Valid Cases \\
\hline Yes & 11 & 14 & 6 & 17.104 & 8 & .029 & 187 \\
\hline No & 0 & 4 & 0 & 22.191 & 8 & .005 & \\
\hline
\end{tabular}

Q1.2: Export Stimulant-Solicited Orders

\begin{tabular}{|l|l|l|l|l|l|l|l|}
\hline Response & $1^{\text {st }}$ Gen. & $2^{\text {nd }}$ Gen. & $3^{\text {rd }}$ Gen. & $\chi 2$ \& Likelihood Ratios & df & Sig & Valid Cases \\
\hline Yes & 15 & 19 & 3 & 18.788 & 8 & .016 & 187 \\
\hline No & 1 & 3 & 2 & 24.768 & 8 & .002 & \\
\hline
\end{tabular}

Q1.3: Export Stimulants-Foreign Travel

\begin{tabular}{|l|l|l|l|l|l|l|l|}
\hline Response & $1^{\text {st }}$ Gen. & $2^{\text {nd }}$ Gen. & $3^{\text {rd }}$ Gen. & $\chi^{2} \&$ Likelihood Ratios & df & Sig & Valid Cases \\
\hline Yes & 8 & 8 & 1 & 18.48 & 8 & .018 & 187 \\
\hline No & 1 & 6 & 4 & 22.401 & 8 & .004 & \\
\hline
\end{tabular}

Q1.4: Export Stimulants-News Sources

\begin{tabular}{|l|l|l|l|l|l|l|l|}
\hline Response & $1^{\text {st }}$ Gen. & $2^{\text {nd }}$ Gen. & $3^{\text {rd }}$ Gen. & $\chi^{2} \&$ Likelihood Ratios & df & Sig & Valid Cases \\
\hline Yes & 3 & 1 & 2 & 11.649 & 8 & .168 & 187 \\
\hline No & 3 & 10 & 4 & 14.746 & 8 & .064 & \\
\hline
\end{tabular}

Q1.5: Export Stimulants-Friends

\begin{tabular}{|l|l|l|l|l|l|l|l|}
\hline Response & $1^{\text {st }}$ Gen. & $2^{\text {nd }}$ Gen. & $3^{\text {rd }}$ Gen. & $\chi 2$ \& Likelihood Ratios & df & Sig & Valid Cases \\
\hline Yes & 0 & 4 & 0 & 12.045 & 8 & .149 & 187 \\
\hline No & 2 & 8 & 4 & 16.279 & 8 & .039 & \\
\hline
\end{tabular}


Q1.6: Export Stimulants-Business Associates

\begin{tabular}{|l|l|l|l|l|l|l|l|}
\hline Response & $1^{\text {st }}$ Gen. & $2^{\text {nd }}$ Gen. & $3^{\text {rd }}$ Gen. & $\chi 2$ \& Likelihood Ratios & df & Sig & Valid Cases \\
\hline Yes & 10 & 8 & 2 & 15.638 & 8 & .048 & 187 \\
\hline No & 0 & 6 & 3 & 22.372 & 8 & .004 & \\
\hline
\end{tabular}

Q1.7: Export Stimulants- Expand Marketх2s Overseas

\begin{tabular}{|l|l|l|l|l|l|l|l|}
\hline Response & $1^{\text {st }}$ Gen. & $2^{\text {nd }}$ Gen. & $3^{\text {rd }}$ Gen. & $\chi 2$ \& Likelihood Ratios & df & Sig & Valid Cases \\
\hline Yes & 12 & 10 & 3 & 18.64 & 8 & .017 & 187 \\
\hline No & 0 & 7 & 3 & 25.846 & 8 & .001 & \\
\hline
\end{tabular}

Q1.8: Export Stimulants- Other

\begin{tabular}{|l|l|l|l|l|l|l|l|}
\hline Response & $1^{\text {st }} \mathrm{Gen}$. & $2^{\text {nd }} \mathrm{Gen}$. & $3^{\text {rd }} \mathrm{Gen}$. & $\chi^{2} \&$ Likelihood Ratios & $\mathrm{df}$ & Sig & Valid Cases \\
\hline Yes & & 2 & 2 & 13.121 & 4 & .011 & 187 \\
\hline No & & & & 10.836 & 4 & .028 & \\
\hline
\end{tabular}

Table 2. Use of US Department of Commerce Services

Q2.1: Research Foreign Markets (e.g., National Trade Databank)

\begin{tabular}{|l|l|l|l|l|l|l|l|}
\hline Response & $1^{\text {st }}$ Gen. & $2^{\text {nd }}$ Gen. & $3^{\text {rd }}$ Gen. & $\chi 2$ \& Likelihood Ratios & $d f$ & Sig & Valid Cases \\
\hline Unaware & 16 & 17 & 5 & 29.679 & 12 & .003 & 187 \\
\hline Aware & 9 & 7 & 5 & 33.658 & 12 & .003 & \\
\hline Used & 1 & 0 & 0 & & & & \\
\hline
\end{tabular}

Q2.2: Promote Your Products Overseas

\begin{tabular}{|l|l|l|l|l|l|l|l|}
\hline Response & $1^{\text {st }}$ Gen. & $2^{\text {nd }}$ Gen. & $3^{\text {rd }}$ Gen. & $\chi 2$ \& Likelihood Ratios & df & Sig & Valid Cases \\
\hline Unaware & 15 & 11 & 5 & 50.153 & 12 & .000 & 187 \\
\hline Aware & 11 & 6 & 4 & 56.376 & 12 & .000 & \\
\hline Used & 0 & 12 & 1 & & & & \\
\hline
\end{tabular}

Q2.3: Identify Foreign Partners (e.g., Agent Distributor Service)

\begin{tabular}{|l|l|l|l|l|l|l|l|}
\hline Response & $1^{\text {st }}$ Gen. & $2^{\text {nd }}$ Gen. & $3^{\text {rd }}$ Gen. & $\chi 2$ \& Likelihood Ratios & df & Sig & Valid Cases \\
\hline Unaware & 19 & 11 & 5 & 28.3 & 12 & .005 & 187 \\
\hline Aware & 4 & 9 & 5 & 37.076 & 12 & .000 & \\
\hline Used & 3 & 6 & 0 & & & & \\
\hline
\end{tabular}

Q2.4: Check Foreign Partner Credibility (e.g., ....)

\begin{tabular}{|l|l|l|l|l|l|l|l|}
\hline Response & $1^{\text {st }}$ Gen. & $2^{\text {nd }}$ Gen. & $3^{\text {rd }}$ Gen. & $\chi 2$ \& Likelihood Ratios & df & Sig & Valid Cases \\
\hline Unaware & 19 & 17 & 7 & 19.578 & 12 & .076 & 187 \\
\hline Aware & 6 & 6 & 3 & 28.243 & 12 & .005 & \\
\hline Used & 1 & 2 & 0 & & & & \\
\hline
\end{tabular}

Q2.5: Obtain Export Leads

\begin{tabular}{|l|l|l|l|l|l|l|l|}
\hline Response & $1^{\text {st }}$ Gen. & $2^{\text {nd }}$ Gen. & $3^{\text {rd }}$ Gen. & $\chi^{2} \&$ Likelihood Ratios & df & Sig & Valid Cases \\
\hline Unaware & 17 & 11 & 4 & 23.383 & 12 & .025 & 187 \\
\hline Aware & 7 & 9 & 5 & 30.491 & 12 & .002 & \\
\hline Used & 2 & 3 & 1 & & & & \\
\hline
\end{tabular}


Q2.6: Obtaining Export Counseling

\begin{tabular}{|l|l|l|l|l|l|l|l|}
\hline Response & $1^{\text {st }} \mathrm{Gen}$. & $2^{\text {nd }} \mathrm{Gen}$. & $3^{\text {rd }} \mathrm{Gen}$. & $\chi^{2} \&$ Likelihood Ratios & df & Sig & Valid Cases \\
\hline Unaware & & & & & & & \\
\hline Aware & & & & & & & \\
\hline Used & & & & & & & \\
\hline
\end{tabular}

Q2.7: Receiving Customized Research reports

\begin{tabular}{|l|l|l|l|l|l|l|l|}
\hline Response & $1^{\text {st }}$ Gen. & $2^{\text {nd }}$ Gen. & $3^{\text {rd }}$ Gen. & $\chi 2$ \& Likelihood Ratios & df & Sig & Valid Cases \\
\hline Unaware & 17 & 15 & 7 & 21.031 & 12 & .05 & 187 \\
\hline Aware & 5 & 8 & 3 & 29.186 & 12 & .004 & \\
\hline Used & 3 & 1 & 0 & & & & \\
\hline
\end{tabular}

Table 3. Export Payments Arrangements

Q3.1: Export payments-Consignment Sales

\begin{tabular}{|l|l|l|l|l|l|l|l|}
\hline Response & $1^{\text {st }}$ Gen. & $2^{\text {nd }}$ Gen. & $3^{\text {rd }}$ Gen. & $\chi 2$ \& Likelihood Ratios & df & Sig & Valid Cases \\
\hline Unaware & 7 & 7 & 3 & 22.364 & 12 & .034 & 187 \\
\hline Aware & 7 & 14 & 5 & 28.695 & 12 & .003 & \\
\hline Used & 6 & 3 & 2 & & & & \\
\hline
\end{tabular}

Q3.2: Export payments-Open accounts

\begin{tabular}{|l|l|l|l|l|l|l|l|}
\hline Response & $1^{\text {st }}$ Gen. & $2^{\text {nd }}$ Gen. & $3^{\text {rd }}$ Gen. & $\chi 2$ \& Likelihood Ratios & df & Sig & Valid Cases \\
\hline Unaware & 4 & 3 & 0 & 36.633 & 12 & .000 & 187 \\
\hline Aware & 10 & 6 & 9 & 44.660 & 12 & .000 & \\
\hline Used & 9 & 17 & 2 & & & & \\
\hline
\end{tabular}

Q3.3: Export payments-Drafts

\begin{tabular}{|l|l|l|l|l|l|l|l|}
\hline Response & $1^{\text {st }}$ Gen. & $2^{\text {nd }}$ Gen. & $3^{\text {rd }}$ Gen. & $\chi 2$ \& Likelihood Ratios & df & Sig & Valid Cases \\
\hline Unaware & 9 & 4 & 2 & 25.037 & 12 & .015 & 187 \\
\hline Aware & 5 & 10 & 6 & 31.839 & 12 & .001 & \\
\hline Used & 6 & 9 & 1 & & & & \\
\hline
\end{tabular}

Q3.4: Export payments-letters of Credit

\begin{tabular}{|l|l|l|l|l|l|l|l|}
\hline Response & $1^{\text {st }}$ Gen. & $2^{\text {nd }}$ Gen. & $3^{\text {rd }}$ Gen. & $\chi^{2}$ \& Likelihood Ratios & df & Sig & Valid Cases \\
\hline Unaware & 2 & 3 & 0 & 25.72 & 12 & .012 & 187 \\
\hline Aware & 9 & 7 & 6 & 34.458 & 12 & .001 & \\
\hline Used & 13 & 18 & 5 & & & & \\
\hline
\end{tabular}

Q3.5: Export payments-Forfait

\begin{tabular}{|l|l|l|l|l|l|l|l|}
\hline Response & $1^{\text {st }}$ Gen. & $2^{\text {nd }}$ Gen. & $3^{\text {rd }}$ Gen. & $\chi^{2} \&$ Likelihood Ratios & df & Sig & Valid Cases \\
\hline Unaware & 18 & 16 & 8 & 17.261 & 8 & .028 & 187 \\
\hline Aware & 1 & 4 & 1 & 23.698 & 8 & .003 & \\
\hline Used & 0 & 0 & 0 & & & & \\
\hline
\end{tabular}

\section{Q3.6: Export payments-Other}

\begin{tabular}{|l|l|l|l|l|l|l|l|}
\hline Response & $1^{\text {st }}$ Gen. & $2^{\text {nd }}$ Gen. & $3^{\text {rd }}$ Gen. & $\chi 2$ \& Likelihood Ratios & df & Sig & Valid Cases \\
\hline Unaware & & & & 3.243 & 8 & .918 & 187 \\
\hline Aware & & & & 4.05 & 8 & .853 & \\
\hline Used & 1 & 1 & 0 & & & & \\
\hline
\end{tabular}


Table 4. Domestic Intermediaries

Q4.1: Domestic Intermediaries-Piggyback

\begin{tabular}{|l|l|l|l|l|l|l|l|}
\hline Response & $1^{\text {st }}$ Gen. & $2^{\text {nd }}$ Gen. & $3^{\text {rd }}$ Gen. & $\chi^{2} \&$ Likelihood Ratios & df & Sig & Valid Cases \\
\hline Unaware & 19 & 14 & 8 & 35.651 & 12 & .000 & 187 \\
\hline Aware & 5 & 12 & 1 & 42.997 & 12 & .000 & \\
\hline Used & 4 & 1 & 1 & & & & \\
\hline
\end{tabular}

Q4.2: Domestic Intermediaries-Export Trading Companies

\begin{tabular}{|l|l|l|l|l|l|l|l|}
\hline Response & $1^{\text {st }}$ Gen. & $2^{\text {nd }}$ Gen. & $3^{\text {rd }}$ Gen. & $\chi 2$ \& Likelihood Ratios & df & Sig & Valid Cases \\
\hline Unaware & 7 & 6 & 1 & 28.683 & 12 & .004 & 187 \\
\hline Aware & 17 & 14 & 9 & 40.324 & 12 & .000 & \\
\hline Used & 7 & 7 & 0 & & & & \\
\hline
\end{tabular}

Q4.3: Domestic Intermediaries-Export Management Companies

\begin{tabular}{|l|l|l|l|l|l|l|l|}
\hline Response & $1^{\text {st }}$ Gen. & $2^{\text {nd }}$ Gen. & $3^{\text {rd }}$ Gen. & $\chi^{2} \&$ Likelihood Ratios & df & Sig & Valid Cases \\
\hline Unaware & 12 & 9 & 0 & 35.956 & 12 & .000 & 187 \\
\hline Aware & 13 & 14 & 9 & 43.746 & 12 & .000 & \\
\hline Used & 4 & 3 & 2 & & & & \\
\hline
\end{tabular}

Q4.4: Export Stimulant-Foreign Sales Representatives

\begin{tabular}{|l|l|l|l|l|l|l|l|}
\hline Response & $1^{\text {st }}$ Gen. & $2^{\text {nd }}$ Gen. & $3^{\text {rd }}$ Gen. & $\chi^{2} \&$ Likelihood Ratios & df & Sig & Valid Cases \\
\hline Unaware & 8 & 6 & 0 & 27.101 & 12 & .007 & 187 \\
\hline Aware & 15 & 10 & 6 & 37.328 & 12 & .000 & \\
\hline Used & 6 & 10 & 2 & & & & \\
\hline
\end{tabular}

Q4.5: Export Stimulant-Other

\begin{tabular}{|l|l|l|l|l|l|l|l|}
\hline Response & $1^{\text {st }}$ Gen. & $2^{\text {nd }}$ Gen. & $3^{\text {rd }}$ Gen. & $\chi 2$ \& Likelihood Ratios & df & Sig & Valid Cases \\
\hline Unaware & 0 & 0 & 0 & 20.24 & 8 & .009 & 187 \\
\hline Aware & & 1 & & 13.301 & 8 & .102 & \\
\hline Used & & 2 & & & & & \\
\hline
\end{tabular}

